\title{
Análise do princípio da unidade familiar no direito internacional dos refugiados*
}

\section{The principle of family unity in internacional refugee law}

\section{Resumo}

O presente artigo tem como objetivo estudar o princípio da unidade familiar no Direito Internacional dos Refugiados. Os refugiados são forçados a fugir de seu país de origem em virtude de um receio maior quanto à sua vida e liberdade e, em grande parte das situações, essas pessoas se veem obrigadas a abandonar a sua casa e a sua família na busca de um futuro incerto em outro Estado. O princípio da unidade familiar dos refugiados leva em consideração a importância da família como ambiente de afeto e solidariedade indispensável ao desenvolvimento saudável de qualquer ser humano, bem como a situação de vulnerabilidade na qual se encontram essas pessoas, buscando, assim, garantir a dignidade, a felicidade e auxiliá-las na integração local em um país estranho.

Palavras-chave: Entidades familiares. Princípio da unidade familiar. Dignidade da pessoa humana. Refúgio.

\begin{abstract}
This article aims to study the principle of family unity in international refugee law. Refugees are forced to flee their country of origin because of a greater concern about their life and freedom, and in most situations, these people are forced to abandon his home and his family in search of an uncertain future in another state. The principle of family unity of refugees takes into account the importance of family as an environment of affection and solidarity essential to the healthy development of any human being, as well as the vulnerable situation in which these people are looking for, thus ensuring the dignity, happiness and assist them in local integration in a foreign country.
\end{abstract}

Keywords: Family entities. Principle of family unity. Human dignity. Refuge.

* Recebido em 05/10/2011. 


\section{Introdução}

O refugiado é definido pela Convenção das Nações Unidas relativa ao Estatuto dos Refugiados como a pessoa que, em razão de fundados temores de perseguição devido à sua raça, religião, nacionalidade, associação a determinado grupo social ou opinião política, encontra-se fora de seu país de origem e que, por causa dos ditos temores, não pode ou não quer regressar ao seu Estado.

Os refugiados são forçados a fugir de seu país de origem em virtude de um receio maior quanto à sua vida e liberdade e, em grande parte das situações, essas pessoas se veem obrigadas a abandonar a sua casa e a sua família na busca de um futuro incerto em outro Estado.

A família é conceituada modernamente como o espaço de realização pessoal e afetiva de seus membros. A união da família, considerada por excelência o espaço comunitário para realização de uma existência digna e da vida em comunhão com as outras pessoas, é de fundamental importância para o desenvolvimento saudável dos seus integrantes. Nesses termos, a família deve receber toda a proteção necessária por parte da sociedade e do Estado.

Levando em consideração a importância da família como ambiente de afeto e solidariedade indispensável ao desenvolvimento saudável de qualquer ser humano, bem como a situação de vulnerabilidade na qual se encontram as pessoas que se veem obrigadas a fugir do seu Estado de origem para buscar refúgio em outro país, o presente artigo tem como objetivo estudar o princípio da unidade familiar no Direito Internacional dos Refugiados.

Como forma de auxiliar os refugiados na readaptação em um país diverso, bem como garantir a dignidade e a felicidade dessas pessoas, os Estados signatários da Convenção Internacional das Nações Unidas para os Refugiados de 1951 se comprometem com a recomendação explicitada na Ata Final da Conferência que adotou a referida Convenção para que sejam tomadas as medidas necessárias para assegurar a proteção da família do refugiado, garantindo a manutenção da unidade familiar, ainda que os demais membros não preencham os requisitos necessários para receberem o status de refugiado.

Na primeira parte do presente artigo, será apresentada a evolução por que passou o conceito de família, inicialmente vinculado a questões patrimoniais para a fa- mília fundada no afeto, na solidariedade, na cooperação e no respeito à dignidade de cada um de seus membros.

Será demonstrada, ainda, a importância da introdução de novos valores instituídos pela Constituição Federal brasileira de 1988, refletindo as mudanças ocorridas na sociedade, entre elas o reconhecimento da pluralidade de entidades familiares. Com base nesses novos valores, será defendida a tese do reconhecimento das entidades familiares para além daquelas apresentadas de forma expressa pela Constituição Federal, bem como a inexistência de hierarquia axiológica entre as entidades, devendo todas elas receber a mesma proteção e respeito.

No tópico 4, será apresentado o princípio da unidade familiar e a sua ligação com outros princípios que regem as relações de família, como o princípio fundamental da dignidade da pessoa humana; e outros princípios gerais, como os princípios da igualdade, da afetividade, da convivência familiar e da proteção integral da criança, adolescente e idoso. No tópico 5 , será feita uma análise da proteção da família no Direito Internacional.

Finalmente, serão apresentados o instituto jurídico do refúgio e a importância da garantia, por parte dos Estados signatários da Convenção de 51, do princípio da unidade familiar como meio para facilitar a integração do refugiado em outro Estado, bem como garantir uma vida digna e feliz para essas pessoas que já são alvos de fortes padrões de violações de direitos humanos. Será ressaltada também a importância do reconhecimento de um conceito amplo de família (princípio da pluralidade das entidades familiares) como forma de garantir uma proteção abrangente aos refugiados e a seus familiares.

Por fim, para melhor fundamentar o estudo do princípio da unidade familiar dos refugiados, será apresentado no último tópico um caso concreto de solicitação de refúgio no Brasil que envolveu uma extensão da condição de refugiado a título de reunião familiar.

\section{A família: função, evolução e repersonalização}

A família, ao longo da história e de acordo com as mudanças ocorridas no seio das sociedades, representou diferentes funções.

Inicialmente, as relações de família eram tratadas meramente como relações patrimoniais. A família 
desempenhava funções econômicas, políticas, religiosas e procracional, isto é, era constituída unicamente com o fim de gerar descendentes, porque a religião assim determinava e seus membros eram importantes, pois serviam como unidade produtiva para o sustento da família e seguro contra a velhice (LÔBO, 2004).

O termo família, em um primeiro momento, foi utilizado para designar o conjunto de escravos pertencentes a um determinado homem. Na Roma primitiva, família era sinônimo de patrimônio, conforme se encontrava na Lei das Doze Tábuas (NADER, 2006). Posteriormente, o vocábulo passou a designar o conjunto de pessoas submetidas ao pai de família ou o vínculo existente entre aqueles que descendiam de um mesmo tronco; esse tipo de família caracterizou-se pelo domínio do homem (pater famílias) e pela finalidade de procriação (NADER, 2006).

A estrutura da família durante o século XX era patriarcal; essa família tradicional apresentava-se como triplamente desigual: nela, os homens tinham mais valor que as mulheres (poder marital); os pais, maior importância que os filhos (pátrio poder); e os heterossexuais mais direitos que os homossexuais (MORAES, 2008).

As antigas funções desempenhadas pela família tradicional foram perdendo espaço na sociedade moderna; isso se deu, sobretudo, pelas grandes mudanças e inovações sociais provocadas pela liberação sexual; pela progressiva emancipação da mulher, assumindo papel decisivo em vários setores sociais, escolhendo seu próprio caminho; bem como pela drástica redução do número de filhos das entidades familiares e até mesmo o grande número de casais sem filho, por livre escolha (DINIZ, 2002).

Com a Constituição Federal de 1988, o modelo de família mudou na legislação brasileira, pois não havia mais, na sociedade moderna, espaço para a família patriarcal.

A antiga família patriarcal é substituída pela família baseada em valores de solidariedade, respeito, coordenação e comunhão de interesses e de vida (LÔBO, 2004). A família passa por uma revolução com destaque para a afetividade em prejuízo de concepções puramente formais ou patrimoniais (BARROSO, 2008).

A Constituição de 1998 institui novos valores refletindo as mudanças ocorridas na sociedade; dentre esses novos valores, destacam-se o fim da discriminação das entidades familiares não matrimonializadas que passaram a receber tutela idêntica às constituídas pelo casamento (caput, art. 226); a igualdade de direitos e deveres entre homem e mulher na sociedade conjugal (parágrafo $5^{\circ}$ do art. 226) e na união estável (parágrafo $3^{\circ}$ do art. 226); e a igualdade entre filhos de qualquer origem seja biológica ou não biológica, matrimonial ou não (parágrafo $6^{\circ}$ do art. 227).

O escopo precípuo da família passou a ser a solidariedade social e demais condições necessárias ao aperfeiçoamento e ao progresso humano, regido o núcleo familiar pelo afeto, como mola propulsora (FARIAS; ROSENVALD, 2010).

É possível falar em uma repersonalização das relações de família ${ }^{2}$. A família, que antes era vinculada a questões patrimoniais ou meramente procracionais, passou a revalorizar a dignidade humana e a colocar em primeiro plano, como centro da tutela jurídica, o indivíduo:

A família tradicional aparecia através do direito
patrimonial e, após as codificações liberais, pela
multiplicidade de laços individuais, como sujeitos
atomizados. Agora, é fundada na solidariedade e
na cooperação, no respeito à dignidade de cada
um de seus membros, que se obrigam mutuamen-
te em uma comunidade de vida. A família atual é
apenas compreensível como espaço de realização
pessoal e afetiva, na qual os interesses patrimo-
niais perderam seu papel de principal protagonis-
ta. A repersonalização de suas relações revitaliza
as entidades familiares (LÔBO, 2004, p. 138).

É evidente que a família sempre manterá uma natureza patrimonial, todavia, a questão patrimonial passou a ter uma função complementar; a família atual tem como fundamento a valorização do ser, a afetividade, a preocupação com os interesses da pessoa humana acima do interesse econômico ${ }^{3}$.

2 Conforme Paulo Lôbo: "Essas linhas de tendência enquadram-se no fenômeno jurídico-social denominado repersonalização das relações civis, que valoriza o interesse da pessoa humana mais do que as suas relações patrimoniais." (LÔBO, 2004).

3 Nesse sentido, segundo Maria Helena Diniz: "Porém é preciso deixar bem claro que o direito de família, em qualquer uma de suas partes (direito matrimonial, convivencial, parental ou tutelar), não tem conteúdo econômico, a não ser indiretamente, no que concerne ao regime de bens entre os cônjuges ou conviventes, à obrigação alimentar entre parentes, ao usufruto dos pais sobre os bens dos filhos menores, à administração dos bens dos incapazes, e que apenas aparentemente assume a fisionomia de direito real ou obrigacional." (DINIZ, 2002). 
A família cumpre modernamente um papel funcionalizado, devendo, efetivamente, servir como ambiente propício para a promoção da dignidade e a realização da personalidade de seus membros, integrando sentimentos, esperanças e valores, servindo como alicerce fundamental para o alcance da felicidade (FARIAS; ROSENVALD, 2010).

\section{A família: do estado liberal ao estado social}

Do Estado liberal - caracterizado pela limitação do poder político e pela não intervenção nas relações privadas (o Estado não se interessava, portanto, pelas relações de família, relações privadas por excelência) e em questões econômicas - passou-se, no século XX, ao Estado social, que se caracteriza pela ideia de solidariedade social.

No Estado social, prevalece a necessidade de intervenção nas relações privadas e controle econômico, com o objetivo de proteger os mais fracos. O Estado, que antes era ausente e não se interessava pelos assuntos ligados às relações de família, passou a se interessar por tais relações como forma de proteção do espaço familiar .

A proteção do Estado à família é um direito subjetivo público, oponível ao próprio Estado e à sociedade 5 . A família tem especial atenção do Estado, que assegurará sua assistência na pessoa de cada um dos que a integra, criando mecanismos para coibir a violência no âmbito de suas relações (art. 226, parágrafo $8^{\circ}$ da $\mathrm{CF}$ ) e impondo sanções aos que transgridem as obrigações impostas ao convívio familiar.

O Estado, todavia, encontra limites, pois a família é proclamada pela Constituição de 1988 como a base da sociedade; dessa forma, não pode o Estado, impunemente, violar tal instituição, sob pena de atingir a base da sociedade a que serve o próprio Estado (LÔBO, 2004). Apenas em situações que envolvem o interesse social ou público, a decisão deixa de ser exclusiva da fa-

4 "O intervencionismo também alcança a família, com o intuito de redução do quantum despótico dos poderes domésticos, da inclusão e equalização de seus membros, e na compreensão de seu espaço para a promoção da dignidade humana." (LÔBO, 2004).

5 Nesses termos, de acordo com o artigo 16.3 da Declaração Universal dos Direitos do Homem de 1948: "A família é o núcleo natural e fundamental da sociedade e tem direito à proteção da sociedade e do Estado". mília e, nesses casos, faz-se imprescindível o aumento das funções estatais 6 .

\section{As entidades familiares}

No Código Civil de 1916, apenas a família constituída pelo matrimônio merecia atenção; nesse sentido, havia discriminação às pessoas unidas sem casamento $\mathrm{e}$ aos filhos havidos dessas relações (DIAS, 2007).

Ao admitir como legítima apenas a família constituída pelo casamento, o Direito Brasileiro remetia as demais entidades ao âmbito do direito das obrigações, pois elas eram equiparadas a sociedades de fato (LÔBO, 2010).

Com o passar do tempo, foram surgindo novas estruturas de convívio que exigiram uma visão mais ampla do conceito de família. Surgiu também, diante da dificuldade de encontrar um conceito único para família condizente com a evolução social, a necessidade de buscar elementos comuns a todas essas estruturas que permitissem englobá-las no conceito de entidade familiar.

Paulo Lôbo (2004) apresenta três características básicas que devem estar presentes para configurar uma entidade familiar: afetividade como o fundamento e a finalidade da entidade, com o objetivo de constituir família; estabilidade, ou seja, não configura uma entidade familiar relacionamentos casuais e descomprometidos; e ostensibilidade, que determina que os membros da entidade devem se apresentar para a sociedade como família.

Sendo assim, já não fazia mais sentido tutelar e garantir proteção apenas às famílias constituídas pelo casamento. A Constituição Federal de 1988 passou a reconhecer, expressamente no seu artigo 226, a existência de outras entidades familiares além das constituídas pelo

\footnotetext{
6 "Não pode também o Estado deixar de cumprir sua permanente função social de proteção à família, como sua célula mater, sob pena de o próprio Estado desaparecer, cedendo lugar ao caos. Daí o porquê de a intervenção do Estado na família ser fundamental, embora deva preservar os direitos básicos de autonomia. Essa intervenção deve ser sempre protetora, nunca invasiva da vida privada... (VENOSA, 2005).
} 
casamento $^{7}$, garantindo proteção, também, à união estável entre o homem e a mulher (art. 226, parágrafo $3^{\circ}$ ) e às comunidades formadas por qualquer dos pais com seus descendentes (CF art. 226, parágrafo $4^{\circ}$ ), denominada família monoparental ${ }^{8}$.

Importante destacar que os tipos de entidades familiares existentes na realidade social não se limitam àqueles expressos na Constituição; o rol apresentado pela Constituição é meramente exemplificativo9:

Os tipos de entidades familiares explicitados nos parágrafos do art. 226 da Constituição são meramente exemplificativos, sem embargo de serem os mais comuns, por isso mesmo merecendo referência expressa. As demais entidades familiares são tipos implícitos incluídos no âmbito de abrangência do conceito amplo e indeterminado de família indicado no caput. Como todo conceito indeterminado, depende de concretização dos tipos, na experiência da vida, conduzindo à tipicidade aberta, dotada de ductilidade e adaptabilidade (LÔBO, 2002, p. 46).

O que caracteriza a família no mundo moderno é a presença do vínculo afetivo a unir as pessoas com identidade de projetos de vida e propósitos comuns, gerando comprometimento mútuo (DIAS, 2007); tal característica é encontrada em outros tipos de entidades além daquelas enumeradas pela Constituição ${ }^{10}$.

São exemplos de entidades familiares não enumeradas no rol constitucional as uniões homoafetivas - união formada por pessoas do mesmo sexo; a família

\footnotetext{
7 Importante destacar que o novo Código Civil de 2002 não acompanhou totalmente a evolução social por que passou o direito de família, pois várias de suas normas estão fundadas nos paradigmas passados. O novo Código, por exemplo, não contém qualquer norma disciplinadora da família monoparental e em poucos artigos contempla a união estável, outorgando-lhe apenas alguns efeitos jurídicos.

8 "A família monoparental ou unilinear desvincula-se da ideia de um casal relacionado com seus filhos, pois estes vivem apenas com um de seus genitores, em razão de viuvez, separação judicial, divórcio, adoção unilateral, não reconhecimento de sua filiação pelo outro genitor, 'produção independente', etc." (DINIZ, 2002).

9 "É preciso ressaltar que o rol da previsão constitucional não é taxativo, estando protegida toda e qualquer entidade familiar, fundada no afeto, esteja, ou não, contemplada expressamente na dicção legal.” (FARIAS; ROSENVALD, 2010).

10 "Composta por seres humanos, decorre, por conseguinte, uma mutabilidade inexorável na compreensão da família, apresentando-se sob tantas e diversas formas, quantas forem as possibilidades de se relacionar, ou melhor, de expressar amor, afeto. A família, enfim, não traz consigo a pretensão da inalterabilidade conceitual." (FARIAS; ROSENVALD, 2010).
}

anaparental - convivência entre parentes ou mesmo entre pessoas que não sejam parentes dentro de uma mesma estrutura com identidade de propósito; a família pluriparental - estrutura familiar originada no matrimônio ou na união de fato de um casal, na qual um ou os dois integrantes têm filhos provenientes de um casamento ou de uma relação anterior (DIAS, 2007).

Todavia, esse posicionamento de considerar a existência de entidades familiares constitucionalizadas para além do numerus clausus não é unânime na doutrina. É possível afirmar que a maior parte dos civilistas interpreta o artigo 226 da Constituição no sentido de que a Carta Magna apenas tutela os três tipos de entidades familiares expressos, não admitindo, portanto, outros tipos de família além dos previstos, uma vez que a previsão constitucional configuraria um rol taxativo (LÔBO, 2004).

Há ainda parte da doutrina que defende a existência de uma hierarquização axiológica das entidades familiares, sendo que a família constituída pelo casamento teria primazia sobre as demais.

Os defensores dessa última tese levam em consideração não apenas a tradição jurídica que valorizava o matrimônio, mas também o parágrafo $3^{\circ}$ do artigo 226 da Constituição que determina, no tocante à união estável, que a lei deve facilitar a sua conversão em casamento; sendo assim, conforme entendimento desses doutrinadores, a Constituição estaria dando primazia ao casamento, pois, caso contrário, não se faria necessária uma regra que determinasse a facilitação da conversão da união estável em casamento (LÔBO, 2004).

Para esses doutrinadores, a família formada pelo casamento prevalece sobre as demais entidades familiares, devendo os demais tipos de família (união estável e monoparental) receber tutela jurídica limitada.

Apesar de esse entendimento ser defendido por parte da doutrina, é importante ressaltar que não há o que se falar em hierarquia axiológica entre as entidades familiares com primazia do casamento sobre as demais entidades, nem em rol taxativo de entidades familiares.

Decorrem do princípio da dignidade da pessoa humana, princípio que fundamenta o ordenamento jurídico brasileiro, o princípio da igualdade das entidades familiares e o princípio da liberdade de escolher e constituir a entidade familiar, não podendo, portanto, o legis- 
lador definir qual entidade familiar é a melhor ou a mais adequada:

Se as pessoas vivem em comunidades afetivas não explicitadas no art. 226, por livre escolha ou em virtude das circunstâncias existenciais, sua dignidade humana apenas estará garantida com o reconhecimento delas como entidades familiares, sem restrições ou discriminações (LÔBO, 2004, p. 49).

O reconhecimento constitucional do pluralismo das entidades familiares (art. 226 da CF) deixou também implícito o dever de observar o princípio da igualdade das entidades e, consequentemente, a necessidade de garantir idêntica proteção a todas elas.

Ademais, o parágrafo $3^{\circ}$ do artigo 226 da Constituição não obriga a conversão da união estável em casamento, a regra surge apenas como um meio de facilitar, para os companheiros que assim desejarem, o casamento, sem, contudo, retirar a proteção constitucional daqueles que quiserem permanecer em união estável (LÔBO, 2004).

A Constituição não estabelece qualquer hierarquia entre as entidades às quais o Estado empresta especial proteção. Sendo assim, não havendo discriminação expressamente prevista na Constituição, o intérprete ou legislador infraconstitucional não o podem fazer.

A partir da interpretação de alguns preceitos constitucionais, é possível também chegar à conclusão de que as entidades familiares não referidas de forma expressa no artigo 226 estão também incluídas no âmbito de proteção.

Esse é o caso do artigo 226, caput que se refere à família de uma forma geral sem fazer qualquer menção a um tipo específico, como era o caso do artigo $175 \mathrm{da}$ Constituição de 1967/1969 que trazia uma cláusula de exclusão ao expressamente apresentar a locução "famílias constituídas pelo casamento". Com a nova redação trazida pelo artigo 226, caput, essa cláusula de exclusão desapareceu, passando a Constituição a tutelar todo e qualquer tipo família ${ }^{11}$.

$\mathrm{O}$ artigo 226, parágrafo $4^{\circ}$, determina que: "Entende-se, também, como entidade familiar, a comunidade formada por qualquer dos pais e seus descendentes". A in-

${ }^{11}$ Nesse sentido, segundo Paulo Lôbo, "O caput do art. 226 é, consequentemente, cláusula geral de inclusão, não sendo admissível excluir qualquer entidade que preencha os requisitos de afetividade, estabilidade e ostensibilidade". (LÔBO, 2002). terpretação dada a essa regra é a de que o termo "também" apresenta-se como uma cláusula geral de inclusão, deixando claro, portanto, que devem-se considerar as demais entidades familiares não expressas no texto constitucional (LÔBO, 2002).

$\mathrm{O}$ artigo 226, parágrafo $8^{\circ}$ (“O Estado assegurará a assistência à família na pessoa de cada um que a integra, criando mecanismos para coibir a violência no âmbito de suas relações"), bem como os preceitos do artigo 227, que se referem à família de forma geral sem fazer qualquer menção a um tipo específico de entidade familiar, ressaltam que a proteção não deve ser conferida em razão de uma forma específica e formalmente preestabelecida de entidade familiar, mas sim às pessoas que integram tais entidades independentemente da forma de sua composição ${ }^{12}$.

Faz-se necessário também levar em consideração o princípio da máxima efetividade da norma constitucional que determina que, podendo ser atribuído dois sentidos a uma norma, deve-se optar por aquele que lhe confira maior eficácia. Nesses termos, deve-se interpretar o artigo 226 de modo que garanta a inclusão de todas as entidades familiares, pois assim confere maior eficácia aos princípios de "especial proteção do Estado (caput)" e de realização da dignidade pessoal "de cada um dos que a integram" (parágrafo 8) (LÔBO, 2002).

Na legislação infraconstitucional, a Lei Maria da Penha, Lei ${ }^{\circ}{ }^{11.340 / 2006}$, em seu artigo 5º inciso III, conceitua como família qualquer relação de afeto. A referida Lei apresentou, pela primeira vez, uma definição de família baseada na sua conformação atual. A Lei alargou expressamente o conceito de família, não sendo mais possível, portanto, limitar o conceito de entidade familiar ao rol constitucional (DIAS, 2007).

O Superior Tribunal de Justiça (STJ) também tem deixado expresso em suas decisões o conceito ampliado e inclusivo de entidade familiar. O STJ tem incluído os solteiros, a comunidade constituída por parentes (por exemplo, a comunidade familiar formada por irmãos sol-

\footnotetext{
12 "Não é a família que é constitucionalmente protegida, mas o lócus indispensável de realização e desenvolvimento da pessoa humana. Sob o ponto de vista do melhor interesse da pessoa, não podem ser protegidas algumas entidades familiares e desprotegidas outras, pois a exclusão refletiria nas pessoas que a integram por opção ou por circunstancias da vida, comprometendo a realização do princípio da dignidade humana." (LÔBO, 2002). 
teiros) e também os chamados solitários (remanescentes de famílias como, por exemplo, os viúvos e divorciados) no conceito de entidade familiar para fins da aplicação da Lei $n{ }^{\circ} 8009 / 1990$ que trata da impenhorabilidade do bem de família ${ }^{13}$.

A Constituição não apresenta, portanto, um rol taxativo de entidades familiares nem estabelece qualquer hierarquia entre elas. Ao suprimir a cláusula de exclusão que apenas reconhecia a família constituída pelo casamento, a Constituição passou a reconhecer o pluralismo das entidades familiares e a igualdade entre todas elas.

Sendo assim, preenchidos os requisitos de afetividade, estabilidade e ostensibilidade, é possível falar na existência de uma entidade familiar merecedora de proteção do Poder Público, ainda que não mencionada expressamente pelo comando do artigo 226 da Constituição; ademais, não há o que se falar em modelo preferencial de entidade familiar, todas elas merecem a mesma proteção e o mesmo respeito à sua dignidade ${ }^{14}$.

\section{0 princípio da unidade familiar}

O ordenamento jurídico brasileiro constitui um sistema aberto de regras e princípios. As regras jurídicas são "mandamentos definitivos", ou seja, apresentam suporte fático hipotético mais determinado e fechado, cuja medida de aplicação já vem previamente definida. Por outro lado, os princípios são considerados "man-

${ }^{13}$ R. Especial 159.851-SP, DJ de 22.06.98: EXECUÇÃO. EMBARGOS DE TERCEIRO. LEI 8009/90. IMPENHORABILIDADE. MORADIA DA FAMILIA. IRMÃOS SOLTEIROS. OS IRMÃOS SOLTEIROS QUE RESIDEM NO IMÓVEL COMUM CONSTITUEM UMA ENTIDADE FAMILIAR E POR ISSO O APARTAMENTO ONDE MORAM GOZA DA PROTEÇÃO DE IMPENHORABILIDADE, PREVISTA NA LEI 8009/90, NÃO PODENDO SER PENHORADO NA EXECUÇÃO DE DIVIDA ASSUMIDA POR UM DELES. RECURSO CONHECIDO E PROVIDO.

14 "Não há na constituição modelo preferencial de entidade familiar, do mesmo modo não há família de fato, pois contempla o direito à diferença. Quando ela trata da família ela está a referir-se a qualquer das entidades possíveis. Se há família, há tutela constitucional com idêntica atribuição de dignidade" (LÔBO, 2002). damentos de otimização"15, apresentam suporte fático hipotético indeterminado e aberto e, por isso, necessitam da mediação do intérprete para serem aplicados em cada situação ${ }^{16}$.

Ademais, os princípios possuem uma dimensão que as regras não têm: a dimensão do peso ou importância. Enquanto as regras são aplicadas por subsunção (ocorrendo no mundo dos fatos a situação prevista hipoteticamente pela norma, deve ser a consequência jurídica prescrita por aquela norma), os princípios são aplicados por ponderação.

Quando os princípios colidem um com o outro, o intérprete deverá ponderar os valores em causa, o que implica que um deles terá precedência sobre o outro no caso concreto, mas nenhum princípio será excluído do ordenamento jurídico nem terá afastada por completo a sua aplicação; quando, por outro lado, duas regras entram

${ }^{15}$ Nesse sentido, De acordo com Robert Alexy: "El punto decisivo para la distinción entre reglas y principio es que los principios son normas que ordenan que algo sea realizado en la mayor medida posible, dentro de las posibilidades jurídicas y reales existentes. Por lo tanto, los principios son mandatos de optimización, que están caracterizados por el hecho de que pueden ser cumplidos en diferente grado y la medida debida de su cumplimiento no solo depende de las posibilidades reales sino también de las jurídicas. El ámbito de las posibilidades jurídicas es determinado por los principios e reglas opuestos. En cambio, las reglas son normas que solo pueden ser cumplidas o no. Si una regla es valida, entonces de hacerse exactamente lo que ella exige, ni más ni menos. Por lo tanto, las reglas contiene determinaciones en el ámbito de lo fáctica y jurídicamente posible. Esto significa que la diferencia entre reglas y principios es cualitativa e no de grado. Toda norma es o bien una regla o un principio." (ALEXY, 1993).

${ }^{16}$ Segundo Ronald Dworkin, a diferença entre princípios jurídicos e regras jurídicas é de natureza lógica. Os dois conjuntos de padrões apontam para decisões particulares acerca da obrigação jurídica em circunstâncias específicas, mas distinguem-se quanto à natureza da orientação que oferecem: as regras são aplicáveis à maneira do tudo-ou-nada (dados os fatos que uma regra estipula, então ou a regra é válida, e nesse caso a resposta que ela fornece deve ser aceita, ou não é válida, e então, em nada contribui para a decisão) enquanto que os princípios não apresentam consequências jurídicas que se seguem automaticamente quando as condições são dadas. (DWORKIN, 2002). 
em conflito, uma delas não poderá ser válida, devendo, portanto, ser excluída do ordenamento jurídico ${ }^{17}$.

Dentre os diversos princípios jurídicos aplicáveis especificamente ao direito de família, caberá destacar, para fins do presente artigo, o princípio da unidade familiar e a sua ligação com os demais princípios que regem esse ramo do direito.

A família é considerada o núcleo natural e fundamental da sociedade, devendo receber toda a proteção necessária por parte da sociedade e do Estado. Deve-se buscar, portanto, todos os meios necessários para a manutenção e preservação das entidades familiares.

A união da família, considerada por excelência o espaço comunitário para a realização de uma existência digna e da vida em comunhão com as outras pessoas (LÔBO, 2009), é de fundamental importância para o desenvolvimento saudável dos seus integrantes, sobretudo das crianças e adolescentes.

Nesses termos, o princípio da unidade familiar estabelece que o Estado e a sociedade devem empreender todos os esforços necessários para que os membros da família permanecem unidos, impedindo, com isso, que, por motivos alheios a sua vontade, sejam os membros da entidade familiar separados uns dos outros.

O princípio da unidade familiar está intimamente ligado ao princípio fundamental da dignidade da pessoa humana, bem como a outros princípios gerais, como os princípios da igualdade, da afetividade, da convivência familiar e da proteção integral da criança, do adolescente e do idoso.

O princípio da dignidade da pessoa humana (art. $1^{\circ}$, III da CF) é fundamento da ordem jurídica brasileira e é o mais universal de todos os princípios, pois é a partir dele que todos os demais princípios se irradiam (DIAS, 2007).

O constituinte consagrou a dignidade da pessoa humana como valor nuclear da ordem constitucional, fazendo uma clara opção pela pessoa, que passou a ser o centro da proteção jurídica (DIAS, 2007).

\footnotetext{
17 "En los casos concretos los principios tienen diferente peso y que prima el principio con mayor peso. Los conflictos de reglas se llevan a cabo en dimensión de la validez: la colisión de principios - como solo pueden entrar en colisión principios válidos - tiene lugar más allá de la dimensión de la validez, en la dimensión del peso." (ALEXY, 1993).
}

Esse princípio representa não só uma limitação à atuação positiva do Estado, isto é, o dever de abster-se de praticar atos contrários à dignidade humana; mas também um dever de promover essa dignidade por meio de ações positivas, como forma de garantir o mínimo existencial para cada ser humano (DIAS, 2007).

O princípio da unidade familiar encontra o seu fundamento no princípio da dignidade da pessoa humana, pois é dentro do seio familiar que é possível realizar o pleno desenvolvimento e a realização de todos os seus membros, principalmente da criança e do adolescente (DINIZ, 2002).

O princípio da unidade familiar também se vincula ao princípio da igualdade nas relações familiares na medida em que a garantia da união da família não faz distinções em relação aos filhos havidos ou não da relação de casamento, ou por adoção (artigo 227, $\$ 6^{\circ}$ da CF). Com base nessa norma constitucional, todo e qualquer filho gozará dos mesmos direitos e proteção, seja em nível patrimonial, seja na esfera pessoal (FARIAS; ROSENVALD, 2010).

Ademais, a todas as entidades familiares deve ser garantido o direito de permanecerem unidas e que sejam empreendidos todos os esforços necessários para garantir a manutenção dessa união, sem restringir tal proteção a um tipo específico de entidade, como fizeram as Constituições brasileiras anteriores que garantiam proteção especial e exclusiva às famílias unidas pelo casamento.

Como já visto no primeiro capítulo deste artigo, com a evolução das relações de família, o princípio da afetividade passou a se destacar como princípio que fundamenta o próprio direito de família; tal princípio encontra-se implícito na Constituição Federal.

Na relação entre cônjuges e companheiros, o princípio da afetividade incide enquanto houver afetividade real, pois ela é pressuposto da convivência (LÔBO, 2009); sendo assim, o princípio da unidade familiar com relação aos cônjuges e companheiros deve ser protegido enquanto houver essa afetividade real; com o fim da afetividade real, não cabe ao Estado ingerir na vida privada, cabendo somente ao casal a decisão de continuar ou não a convivência.

Por outro lado, com relação aos filhos, a afetividade não se confunde com o afeto. A afetividade é dever imposto aos pais em relação aos filhos e destes em rela- 
ção àqueles, ainda que haja desamor ou desafeição entre eles (LÔBO, 2009). Com relação aos filhos, o princípio da unidade familiar deve sempre ser preservado, ainda que os genitores não estejam mais convivendo; tal manutenção do princípio da unidade familiar é viável por meio da guarda compartilhada (Lei 11.698/2008) ${ }^{18}$.

A manutenção da união da família tem como fundamento lógico a garantia do direito de convivência dos seus membros (princípio da convivência familiar), não permitindo que, por motivos alheios a sua vontade, sejam as famílias separadas e que seja usurpado delas o direito de conviver.

Paulo Lôbo (2009) define a convivência familiar como a relação afetiva diuturna e duradoura entretecida pelas pessoas que compõem o grupo familiar, em virtude de laços de parentesco ou não, no ambiente comum.

No tocante à criança e ao adolescente, a garantia do direito à convivência familiar é dirigida à família e a cada membro dela, além de ao Estado e à sociedade como um todo (art. 227, CF). O direito à convivência familiar busca fortalecer os vínculos familiares e deve, portanto, ser assegurado a toda criança e adolescente como meio para garantir a sua dignidade e o seu desenvolvimento integral enquanto pessoa humana (DIAS, 2007).

Com base no princípio da proteção integral a crianças, adolescentes (art. 227, CF) e idosos (art. 230, $\mathrm{CF})$, resta clara a importância da manutenção da unidade da família para a proteção dessas pessoas, tendo em vista a sua maior vulnerabilidade e fragilidade, merecendo, portanto, um tratamento especial ${ }^{19}$.

\section{A família no direito internacional}

A proteção da família no Direito Internacional encontra previsão na Declaração Universal dos Direitos do Homem, votada pela Organização das Nações Unidas

\footnotetext{
18 "A cessação da convivência entre os pais não faz cessar a convivência familiar entre os filhos e seus pais, ainda que estes passem a viver em residências distintas." (LÔBO, 2010).

${ }^{19} \mathrm{O}$ Estatuto da Criança e do Adolescente (ECA - Lei 8.069/1990) estabelece, dentre outros direitos, o direito à convivência familiar e comunitária, assegurando o direito da criança e do adolescente de ser criado e educado no seio da própria família. No Estatuto do Idoso (Lei n. 8.842/1994), destaca-se a regra que determina atendimento do idoso pela própria família em detrimento do atendimento asilar.
}

(ONU) em 10 de dezembro de 1984, assegura às pessoas humanas o direito de fundar uma família (art. 16, parágrafo $\left.1^{\circ}\right)^{20} \mathrm{e}$, em seu artigo 16 , parágrafo $3^{\circ}$, prevê que "a família é o núcleo natural e fundamental da sociedade e tem direito à proteção da sociedade e do Estado".

A necessidade da intervenção protetora do Estado na família é, portanto, um fato universalmente aceito e adotado nas constituições da maioria dos países, independentemente do sistema político ou ideológico (LÔBO, 2010), pois o poder público de todas as nações pretende garantir a família, protegendo-a, evitando abusos, propiciando melhores condições de vida às novas gerações, ajudando-a a exercer beneficamente seus poderes, criando órgãos sociais que a tutelam (DINIZ, 2002).

A maior parte dos instrumentos internacionais relativos aos direitos humanos contém disposições similares para a proteção da família como, por exemplo, a Convenção Americana de Direitos Humanos de 1969 - Pacto São José da Costa Rica (artigos 11.2 e 17); a Convenção sobre a Eliminação de Todas as Formas de Discriminação contra as Mulheres de 1979 (artigo 10, h); e a Convenção Internacional sobre Direitos da Criança de 1889 (artigos 5 e 16).

Para fins do presente artigo, faz-se necessário destacar a Convenção Internacional das Nações Unidas para os Refugiados de 1951. A Ata Final da Conferência que adotou a Convenção de 1951 recomendou que os Governos tomassem as medidas necessárias para assegurar a proteção da família do refugiado, garantindo a manutenção da unidade familiar e a proteção dos refugiados menores, em particular crianças não acompanhadas e meninas, com especial referência para a tutela e adoção.

Tratando da questão dos refugiados, a Convenção Internacional sobre Direitos da Criança de 1889 também determina, em seu artigo 22, que os Estados-Partes cooperem no sentido de proteger e ajudar a criança refugiada e de localizar seus pais ou outros membros de sua família a fim de obter informações necessárias que permitam sua reunião com a família.

${ }^{20}$ Art. 16, parágrafo $1^{\circ}$ da Declaração Universal dos Direitos do Homem: "Os homens e mulheres de maior idade, sem qualquer restrição de raça, nacionalidade ou religião, têm o direito de contrair matrimônio e fundar uma família. 


\section{0 instituto jurídico do refúgio}

Desde o início do século XX, a questão dos refugiados tornou-se uma preocupação da comunidade internacional, porém a efetiva proteção internacional dos refugiados surge apenas com a Sociedade das Nações.

Durante a Primeira Guerra Mundial, surgem os primeiros problemas de movimentos massivos e a necessidade de a comunidade internacional definir a condição jurídica dos refugiados e realizar atividades de socorro, bem como organizar assentamentos e a questão da repatriação; mas, foi durante a Segunda Guerra Mundial que o problema dos refugiados tomou grandes proporções com o deslocamento de milhões de pessoas por várias partes do mundo (SOARES, 2009).

Em 1951, com a função de garantir proteção internacional aos refugiados, é criado, no âmbito do Secretariado da ONU, o Alto Comissariado das Nações Unidas para os Refugiados (ACNUR): instituição apolítica, humanitária e social. Foi construído ainda na ONU o Fundo de Emergência das Nações Unidas para os refugiados e instituído o ano do refugiado (de junho de 1959 a junho de 1960) com o intuito de chamar a atenção da opinião pública mundial para essa questão (SOARES, 2009).

Diante dos efeitos devastadores gerados no mundo decorrentes da Segunda Guerra Mundial, a ONU elaborou uma Convenção para regular a situação jurídica dos refugiados. A Convenção foi aprovada pela Assembleia Geral da ONU em 28 de julho de 1951 e sua vigência teve início em 21 de abril de 1954.

A Convenção, todavia, estava limitada no tempo, pois só era aplicada para os refugiados que tinham essa condição decorrente dos acontecimentos ocorridos antes de $1^{\circ}$ de janeiro de 1951, ou seja, para tratar das situações decorrentes do pós-Segunda Guerra Mundial. A Convenção apresentava ainda uma reserva geográfica, pois concedia aos signatários a faculdade de aplicá-la apenas às situações dos refugiados no continente europeu (AGUIAR, 2001).

Com o passar do tempo e diante do aparecimento de novas situações de refugiados no mundo, surgiu a necessidade de ampliar as disposições da Convenção de 1951. O Protocolo relativo ao Estatuto dos Refugiados de 1967 ampliou o conceito de refugiados no tocante ao limite temporal e geográfico, permitindo que os dispositivos da Convenção pudessem ser aplicados aos refugiados sem considerar a data limite de $1^{\circ}$ janeiro de 1951 para os casos de refugiados em todo o mundo e não mais apenas no continente europeu (AGUIAR, 2001).

O refugiado é definido pela Convenção das Nações Unidas relativa ao Estatuto dos Refugiados como a pessoa que, em razão de fundados temores de perseguição devido à sua raça, religião, nacionalidade, associação a determinado grupo social ou opinião política, encontra-se fora de seu país de origem e que, por causa dos ditos temores, não pode ou não quer regressar ao seu Estado ${ }^{21}$.

A problemática dos refugiados está intimamente ligada à questão dos direitos fundamentais da pessoa humana. Quando uma pessoa se vê diante de uma situação em que é forçada a abandonar seu lar para escapar de algum tipo de perseguição, uma série de direitos humanos é violada: o direito à vida e à vida familiar, à liberdade, à privacidade, à liberdade de locomoção e residência, à segurança pessoal, o direito de não ser submetido à tortura e ao exílio arbitrário (PIOVESAN, 2003).

Ao acolher uma pessoa como refugiada em seu território, o Estado de acolhida se obrigará a proteger seus direitos, a garantir um refúgio seguro e a tratar com dignidade a pessoa do refugiado. Por outro lado, o refugiado tem deveres para com o país em que se encontra, os quais compreendem notadamente a obrigação de se conformar às leis e aos regulamentos, assim como às medidas tomadas para a manutenção da ordem pública ${ }^{22}$.

Ao ser reconhecido como refugiado, a Convenção relativa ao Estatuto dos Refugiados de 1951 confere à pessoa direitos humanos fundamentais como: o direito de não sofrer discriminação por motivo de raça, religião ou país de origem (art. 3); o direito à liberdade religiosa e liberdade de instrução religiosa de seus filhos (art. 4); o direito à aquisição de propriedade (art. 13); a proteção à propriedade intelectual e industrial (art. 14); o direito de associação (art. 15); o direito de livre acesso ao Poder Judiciário e à assistência jurídica (art. 16); o direito ao trabalho (art. 17); o direito à educação, devendo os Estados conceder aos refugiados o mesmo tratamento que os nacionais em matéria de ensino primário (art. 22); documentos de identidade (art. 27) etc.

${ }^{21}$ Cf. art. $1^{\circ}$ da Convenção das Nações Unidas Relativa ao Estatuto dos Refugiados, 1951.

${ }^{22}$ Cf. art. $2^{\circ}$ da Convenção das Nações Unidas Relativa ao Estatuto dos Refugiados, 1951. 
Dentre os direitos garantidos a uma pessoa reconhecida como refugiada, cabe ressaltar, para fins do presente artigo, o direito à unidade familiar, corolário do princípio da dignidade da pessoa humana.

Levando em consideração a imprescindibilidade de se preservar a dignidade dessas pessoas que já se encontram em situação bastante vulnerável, a Ata Final da Conferência de 1951 recomendou aos Governos que tomassem as medidas necessárias para a proteção da família do refugiado, em especial quanto a assegurar que a unidade da família do refugiado seja mantida.

Os refugiados são forçados a fugir de seu país de origem em virtude de um receio maior quanto à sua vida e liberdade e, em grande parte das situações, essas pessoas se veem obrigadas a abandonar sua casa, família e bens na busca de um futuro incerto em outro Estado.

Os problemas enfrentados pelos refugiados não cessam após eles serem reconhecidos como tais e acolhidos em um país que se comprometa a garantir a sua proteção. Após a concessão do refúgio, essas pessoas se veem obrigadas a se adaptarem a um país diferente, sob pena de viverem isoladas e não alcançarem os meios adequados para a sua subsistência.

Como forma de auxiliar essas pessoas na readaptação em um país diverso, bem como garantir a sua dignidade e felicidade, os Estados devem garantir todos os meios para manutenção da unidade familiar do refugiado.

\section{0 princípio da unidade da família no direito internacional dos refugiados}

Inspirando-se na Declaração Universal dos Direitos do Homem, a qual estipula que a "família é a unidade de grupo natural e fundamental da sociedade e tem direito a ser protegida pela sociedade e pelo Estado", a maior parte dos instrumentos internacionais relativos aos direitos humanos contém disposições similares para a proteção da unidade da família.

A Ata Final da Conferência que adotou a Convenção de 1951 recomendou que os Governos tomassem as medidas necessárias para assegurar a proteção da família do refugiado.

A recomendação feita pela Ata Final da Conferência com relação à proteção da família do refugiado desdobra-se em duas situações: a primeira determina que seja assegurada a unidade da família do refugiado, ou seja, sendo reconhecida uma pessoa como refugiada, que sejam empreendidos os esforços necessários para garantir que a família daquele refugiado permaneça unida no país de abrigo, especialmente nos casos em que o chefe de família tenha preenchido as condições necessárias para a sua admissão em um determinado país; a segunda situação requer que sejam tomadas as medidas cabíveis para assegurar a proteção dos refugiados menores, sobretudo as crianças desacompanhadas e as meninas, com especial referência para a tutela e adoção (ACNUR, 2009).

Cabe ressaltar que a Convenção de 1951 não introduz o princípio da unidade familiar na definição do termo de refugiado. Todavia, as recomendações da Ata Final da Conferência são observadas pela maioria dos Estados, quer sejam ou não partes da Convenção de 1951 ou do Protocolo de $1967^{23}$.

De acordo com o princípio da unidade familiar, caso o chefe de família preencha os critérios necessários para ser reconhecido como refugiado, deverá ser também concedido aos seus familiares dependentes a condição de refugiado, ainda que eles não preencham os requisitos formais para serem assim reconhecidos (ACNUR, 2009).

A concessão de refúgio nesses casos se dá unicamente em virtude da proteção à família, garantindo a manutenção da convivência unida de seus membros.

A condição de refugiado não será formalmente concedida a um dependente apenas se isso for incompatível com a sua condição jurídica pessoal como, por exemplo, um dependente membro de uma família de refugiados que seja nacional do país de refúgio ou de qualquer outro país, gozando da sua proteção. Nessas circunstâncias, não se justifica que lhe seja concedida a condição de refugiado. No que se refere aos membros da família que podem se beneficiar do princípio da unidade familiar, deverão, pelo menos, ser incluídos o cônjuge e os filhos menores (ACNUR, 2009).

\footnotetext{
${ }^{23}$ A Lei brasileira 9.474/1997, em seu artigo $2^{\circ}$, adotou a recomendação prevista na Ata Final da Conferência de 1951 ao determinar que os efeitos da condição dos refugiados serão extensivos ao cônjuge, aos ascendentes e descendentes, assim como aos demais membros do grupo familiar que do refugiado dependerem economicamente, desde que se encontrem em território nacional.
} 
Dentre os novos valores instituídos pela Constituição Federal de 1988, refletindo as mudanças ocorridas na sociedade, tem-se o reconhecimento do pluralismo das entidades familiares. É preciso, portanto, considerar o conceito ampliado de entidade familiar para esclarecer que não só o cônjuge do refugiado, como também o companheiro (união estável ou união homoafetiva) recebe a proteção da unidade familiar.

Ademais, não há o que se falar em distinção de filhos; sendo eles menores, de origem biológica ou não biológica, matrimonial ou não, receberão a mesma proteção.

Ainda no tocante ao conceito ampliado de família, bem como levando em consideração o princípio da dignidade da pessoa humana, outras pessoas, como pais idosos dos refugiados e demais membros do grupo familiar que do refugiado dependerem economicamente, são normalmente incluídas se viverem em comunhão de habitação (ACNUR, 2009).

Por outro lado, se o chefe de família não é refugiado, nada impede que qualquer um dos seus familiares dependentes, caso possa invocar a título individual as suas próprias razões, peça o reconhecimento do estatuto de refugiado segundo a Convenção de 1951 e o Protocolo de 1967. Pode-se concluir, dessa forma, que o princípio da unidade familiar exerce-se a favor dos membros dependentes e não contra eles (ACNUR, 2009).

\section{0 princípio da unidade da família no direito interno: análise do caso concreto $\mathbf{~ k m}^{24}$}

O Brasil é um país que tem tradição na concessão de abrigo e proteção a pessoas perseguidas por motivos políticos, raciais e sociais. O instituto jurídico do refúgio no Brasil é regulado pela Lei 9.474/1997 que define os mecanismos para a implementação do Estatuto dos Refugiados no Brasil.

Na esfera nacional, o Comitê Nacional para os Refugiados (CONARE) é o órgão de deliberação, no âmbito do Ministério da Justiça, encarregado de tomar decisões em matéria de refúgio. É competência do CONARE, como primeira instância, analisar o pedido e declarar o

${ }^{24}$ Processo $\mathrm{n}^{\mathrm{o}} \mathrm{MJ}$ 08460.006496/2004-51. Importante destacar que o processo de solicitação de refúgio tem caráter sigiloso. (LEÃO, 2009). reconhecimento da condição de refugiado e decidir também acerca da cessação e da perda dessa condição ${ }^{25}$.

O CONARE também é responsável pela implementação das políticas públicas para os refugiados no Brasil - por meio da orientação e coordenação das ações necessárias à eficácia da proteção, assistência e apoio jurídico aos refugiados - e ainda por aprovar instruções normativas ${ }^{26}$ para esclarecimentos quanto à execução da Lei 9.474/1997, visando a sua melhor implementação ${ }^{27}$.

Como visto, o artigo $2^{\circ}$ da Lei Nacional 9.474/1997 possibilita aos refugiados reconhecidos pelo Brasil reunirem-se com seu grupo familiar uma vez que estes se encontrem em território nacional. Essa reunião perdurará enquanto existir a necessidade de proteção outorgada pelo Estado brasileiro.

A Resolução Normativa no 4 do CONARE, de $1^{\circ}$ de dezembro de 1998 (CONARE, 1998), vislumbra esse artigo como uma extensão da condição de refugiado a título de reunião familiar. Trata-se, portanto, de uma faculdade outorgada pelo Estado brasileiro aos refugiados, possibilitando a eles reunirem-se com a sua família.

A Resolução do CONARE leva em consideração o conceito amplo de família, observando o princípio do pluralismo das entidades familiares e da dignidade da pessoa humana, e reconhece expressamente como dependentes o cônjuge; os filhos solteiros, menores de 21 anos, naturais ou adotivos, ou maiores quando não puderem prover o próprio sustento; ascendentes; e irmãos, netos, bisnetos ou sobrinhos, se órfãos, solteiros e menores de 21 anos, ou de qualquer idade quando não puderem prover o próprio sustento (CONARE, 1998).

${ }^{25}$ Cf. art. 12 da Lei 9.47497.

${ }^{26}$ Atualmente, existem 13 Resoluções Normativas em vigor: Resolução Normativa 1 (modelo do termo de declaração a ser preenchido na Polícia Federal); 2 (modelo do questionário a ser preenchido nos Centros de Acolhida para Refugiados); 3 (modelo do termo de responsabilidade do refugiado); 4 (solicitação de reunião familiar); 5 (autorização para viagem internacional); 6 (concessão do protocolo provisório); 7 (adoção de prazos e atendimentos a convocações); 8 (notificação de indeferimento da solicitação de refúgio); 9 (local para preenchimento de questionário); 10 (refugiados com residência definitiva no Brasil); 11 (publicação da notificação); 12 (viagens internacionais e perda do status de refugiado); e 13 (Resolução Recomendada CNI 8).

${ }^{27}$ Cf. art. 12 e seus incisos da Lei 9.474/1997. 
Apesar de não estar expresso na referida Resolução, diante do artigo 226 da Constituição Federal brasileira, bem como dos princípios que regem o direito de família, pode-se concluir que não só o cônjuge do refugiado, como também o companheiro (união estável ou união homoafetiva) recebe a proteção da unidade familiar.

Para melhor fundamentar o presente estudo acerca do princípio da unidade familiar dos refugiados, será apresentado um caso concreto de solicitação de refúgio no Brasil analisado pelo CONARE, que envolve uma extensão da condição de refugiado a título de reunião familiar.

O caso a ser analisado é o do solicitante $K M$ que veio ao Brasil em busca de reunião familiar com sua mãe, aqui refugiada desde 1993 (LEÃO, 2009). A família é oriunda da República Democrática do Congo. A mãe fugiu desse país em virtude de uma onda de repressão a um partido de oposição, do qual seu esposo era motorista. Foi obrigada a deixar a família para trás, pois um dia, ao chegar a sua casa, encontrou-a cercada por policiais.

Foi para Luanda, onde ficou na casa de uma amiga que lhe conseguiu a passagem para o Brasil. Os filhos ficaram algum tempo na casa da avó e depois voltaram para a companhia do pai, que se deslocou para outra província. E, uma vez passada a crise, casou-se novamente.

A mãe conseguiu manter contato com os filhos até 1994. O solicitante sempre soube que sua mãe se encontrava no Brasil. Tinha a intenção de reencontrá-la. Ele relatou que saiu da casa do pai devido aos maus tratos da madrasta e foi para a África do Sul com alguns amigos.

Posteriormente, foi para Angola onde obteve uma passagem para vir ao Brasil à procura da mãe. Ao chegar a São Paulo, o solicitante conheceu um congolês, na Cáritas $^{28}$, que reconheceu sua mãe em uma foto antiga. Levou-o à Cáritas do Rio de Janeiro e ela promoveu o seu encontro com a mãe. No momento do pedido de reunião familiar, o solicitante tinha 22 anos recém-completados.

Conforme visto, de acordo com a Resolução Normativa n. ${ }^{\circ} 4$ do CONARE, os efeitos da condição de refugiado poderão ser estendidos aos filhos solteiros menores

\footnotetext{
${ }^{28}$ A Cáritas é uma organização não governamental ligada à Igreja Católica que atua mundialmente em diversos projetos sociais, dentre os quais, a acolhida aos refugiados que ocorre por meio da defesa da criação de condições favoráveis de acolhida, proteção e integração social. (JUBILUT, 2009).
}

de 21 anos ou àqueles que não puderem prover o seu próprio sustento (LEÃO, 2009).

Todavia, neste caso concreto, o CONARE considerou que, apesar da maioridade do solicitante, estava claro que ele efetivamente buscava a reunião familiar há quase 8 anos, ou seja, antes de atingir a maioridade.

Ademais, havia suspeitas de que a mãe fosse soropositiva e, nesse caso, a unidade familiar cumpriria um importante papel de rede informal de apoio social, cujo filho desempenharia um rol fundamental.

É importante destacar que o instituto da reunião familiar tem, sobretudo, objetivo humanitário, colaborando sensivelmente para a integração local dos refugiados (LEÃO, 2009). A integração dessas pessoas que já se encontram em uma situação de total fragilidade e vulnerabilidade, em um país diferente do seu, é bastante difícil; tal situação pode ser amenizada a partir da reunião dos familiares dos refugiados no país de abrigo, possibilitando a essas pessoas uma chance de refazer as suas vidas perto dos seus entes queridos.

Nesse caso, levando em consideração o artigo $3^{\circ} \mathrm{da}$ Resolução Normativa n. ${ }^{\circ} 4$ do CONARE (CONARE, 1998) que determina que as situações não previstas nesta Resolução poderão ser objeto de apreciação pelo CONARE, o Comitê deferiu a solicitação feita por $K M$ por ter considerado que o caso se revestia de especial interesse humanitário, consagrando os princípios que norteiam o instituto da reunião familiar nas situações de refugiados (LEÃO, 2009).

\section{Conclusão}

A problemática dos refugiados está intimamente ligada à questão dos direitos fundamentais da pessoa humana. Quando uma pessoa se vê diante de uma situação em que é forçada a abandonar seu lar para escapar de algum tipo de perseguição, uma série de direitos humanos é violada, dentre eles, o direito à vida familiar.

A proteção da família, ambiente de afeto e solidariedade, indispensável para o desenvolvimento saudável de qualquer ser humano, é garantida por meio de diversos instrumentos internacionais que enfatizam a importância da intervenção protetora do Estado na família como forma de protegê-la, propiciando melhores condições de vida. 
A recomendação prevista na Ata Final da Conferência da Convenção de 1951 com relação à proteção da família do refugiado deve, portanto, ser estritamente observada por todos os Estados, devendo estes empreender todos os esforços necessários para garantir que a família daquele refugiado permaneça unida no país de abrigo, levado em consideração que o instituto da reunião familiar tem, sobretudo, objetivo humanitário, colaborando sensivelmente para a integração local dos refugiados.

No que se refere aos membros da família que podem se beneficiar do princípio da unidade familiar, a Ata Final da Conferência da Convenção de 1951 prevê que deverão pelo menos ser incluídos o cônjuge e os filhos menores.

Para que seja garantida proteção ampla e efetiva aos refugiados e à sua família, faz-se necessário, todavia, levar em consideração as mudanças ocorridas na sociedade e a consequente evolução sofrida pelo direito de família com o surgimento de novas formas de convivência, baseadas no afeto, que merecem idêntica tutela jurídica.

Nesse sentido, deve-se estender a proteção, garantindo os meios necessários para reunião não só do cônjuge do refugiado, como do companheiro (união estável ou união homoafetiva), e também assegurar que não exista distinção de filhos - sendo estes menores, de origem biológica ou não biológica, matrimonial ou não, receberão a mesma proteção.

A legislação brasileira que trata da questão dos refugiados andou bem nesse assunto e deve servir de parâmetro para os demais países, pois confere proteção ampla aos refugiados ao determinar que os efeitos da condição dos refugiados sejam extensivos ao cônjuge, aos ascendentes e descendentes, assim como aos demais membros do grupo familiar que do refugiado dependerem economicamente (art. $2^{\circ}$ da Lei 9.474/1997).

A Resolução do $n^{\circ} 4$ do CONARE reconhece como dependentes o cônjuge; os filhos solteiros, menores de 21 anos, naturais ou adotivos, ou maiores quando não puderem prover o próprio sustento; ascendentes; e irmãos, netos, bisnetos ou sobrinhos, se órfãos, solteiros e menores de 21 anos, ou de qualquer idade quando não puderem prover o próprio sustento.

Por fim, importa ressaltar que, apesar de não estar expresso na referida resolução a proteção dos compa- nheiros unidos por união estável ou união homoafetiva, infere-se, a partir de uma análise sistemática da legislação nacional, que eles estão sim abarcados pela proteção dada pelo princípio da unidade familiar, tendo em vista o artigo 226 da Constituição Federal brasileira e os diversos princípios que regem o direito de família, dentre eles o princípio da dignidade da pessoa humana e da pluralidade das entidades familiares.

\section{Referências}

ACNUR. Manual de Procedimentos e Critérios a Aplicar para Determinar o Estatuto do Refugiados: de acordo com a Convenção de 1951 e o Protocolo de 1967 relativos ao ACNUR. Nota de orientação sobre extradição e proteção internacional de refugiados. Genebra, 2008.

AGUIAR, Renan. Lei 9.474/97: cláusulas de inclusão e exclusão. In: ARAÚJO, Nadia de; ALMEIDA, Guilherme Assis de. $O$ direito internacional dos refugiados: uma perspectiva brasileira. Rio de Janeiro: Renovar, 2001.

ALEXY, Robert. Teoría de los derechos fundamentales. Madrid: Centro de estudios constitucionales, 1993.

BARROSO, Luís Roberto. A Constitucionalização do Direito e o Direito Civil. In: TEPEDINO, Gustavo (Org.). Direito civil contemporâneo: novos problemas à luz da legalidade constitucional: anais do Congresso Internacional de Direito Civil-Constitucional da Cidade do Rio de Janeiro. São Paulo: Atlas, 2008. p. 238-261.

BRASIL. Lei no 9.474, de 22 de julho de 1997. Disponível em: <www.planalto.gov.br>. Acesso em: 10 abr. 2009.

CONARE. Resoluções Normativas do Comitê Nacional para Refugiados. Disponível em: <www.acnur.org>. Acesso em: 8 maio 2009.

DIAS, Maria Berenice. Manual de direito das famílias. 4. ed. rev. atual. ampl. São Paulo: Revista dos Tribunais, 2007.

DINIZ, Maria Helena. Curso de direito civil brasileiro. 18. ed. aum. e atual. de acordo com o novo Código Civil. São Paulo: Saraiva, 2002.

DWORKIN, Ronald. Levando os direitos a sério. São Paulo: M. Fontes, 2002.

JUBILUT, Liliana Lyra. O direito internacional dos refugiados e a sua aplicação no ordenamento jurídico. São Paulo: Método, 2007. 
FARIAS, Cristiano Chaves de; ROSENVALD, Nelson. Direito das famílias. 2. ed. rev. ampl. e atual. Rio de Janeiro: Lumen Juris, 2010.

LEÃO, Renato Zerbini Ribeiro. Memória anotada, comentada e jurisprudencial para os refugiados (CONARE). Disponível em: <www.acnur.org/biblioteca/ pdf/5405.pdf.>. Acesso em: 8 abr. 2009.

LÔBO, Paulo Luiz Netto. A nova principiologia do direito de família e suas repercussões. In: HIRONAKA, Giselda Maria Fernandes Novaes; TARTUCE, Flávio; SIMÃO, José Fernando (Org.). Direito de família e das sucessões: temais atuais. São Paulo: Método, 2009. p. 1-20.

LÔBO, Paulo Luiz Netto. A repersonalização das relações de família. Revista Brasileira de Direito de Família, Porto Alegre, n. 24, p. 136-156, jun./jul. 2004.

LÔBO, Paulo Luiz Netto. Direito civil: famílias. 3. ed. São Paulo: Saraiva, 2010.

LÔBO, Paulo Luiz Netto. Entidades familiares constitucionalizadas: para além do numerus clausus. Revista Brasileira de Direito de Família, Porto Alegre: Síntese, n. 12, p. 40-55, jan./mar. 2002.

MORAES, Maria Celina Bodin de. Perspectivas a partir do direito civil-constitucional. In: TEPEDINO, Gustavo (Org.). Direito civil contemporâneo: novos problemas à luz da legalidade constitucional: anais do Congresso Internacional de Direito Civil-Constitucional da Cidade do Rio de Janeiro. São Paulo: Atlas, 2008. p. 29-41.
NADER, Paulo. Curso de direito civil: direito de família. Rio de Janeiro: Forense, 2006.

ONU. Convenção Internacional sobre Direitos da Criança. Disponível em: <http://www.onu-brasil.org.br/doc_ crianca.php>. Acesso em: 16 fev. 2011.

ONU. Declaração Universal dos Direitos do Homem. Diponível em:< http://www.onu-brasil.org.br/ documentos_direitoshumanos. php $>$. Acesso em: $16 \mathrm{fev}$. 2011.

ONU. ACNUR. Convenção Relativa ao Estatuto dos Refugiados. 1951. Disponível em: <http://www2.mre.gov. br/dai/refugiados.htm>. Acesso em: 7 abr. 2009.

PIOVESAN, Flávia. Temas de direitos humanos. 2. ed. São Paulo: M. Limonad, 2003. p. 118.

SOARES, Guido. Direitos humanos, direitos dos refugiados $e$ direito humanitário. Disponível em: <http:://www. leonildocorrea.adv.br/curso/guido1.htm>. Acesso em: 28 mar. 2009.

VENOSA, Sílvio de Salvo. Direito civil: direito de família. 5. ed. São Paulo: Atlas, 2005. 
Para publicar na revista

Universitas Relações Internacionais,

entre no endereço eletrônico www.publicacoesacademicas.uniceub.br. Observe as normas de publicação, facilitando e agilizando o trabalho de edição. 